\title{
TÉCNICAS NARRATIVAS EN DE EXPUGNATIONE THESSALONICAE DE JUAN KAMINIATES
}

\author{
Spyros P. Panagopoulos \\ Department of History, Ionian University, Corfu. Greece
}

\begin{abstract}
Resumen: El presente artículo se ocupa de las técnicas narrativas - cómo el escritor Juan Kaminiates decide contar su historia: la captura de Salónica en 904 por los piratas árabes y el encanto que siguió y el transporte de miles de habitantes a Siria. Diversos aspectos de la función narrativa se examinan: la relación entre el tiempo de la historia y el tiempo del discurso, la forma y el contenido de la descripción, las funciones del narrador y la comunicación con el lector, la importancia del detalle, el uso de los proverbios y las metáforas. Por último, un análisis indicativo de los formularios escritos influyentes en la obra de Kaminiates, se trató también en el marco de este análisis narrativo.
\end{abstract}

Palabras clave: Juan Kaminiates, Salónica, Árabes, técnicas narrativas, ekphrasis, Progymnásmata, ethopoeia, narración, epistolografía, homeoteleuton, hipérbaton, tautología, nominalización adjetivo

\section{NARRATIVE TECHNIQUES IN JOHN KAMINIATES' $D E$ EXPUGNATIONE THESSALONICAE}

Abstract: This paper is concerned with narrative techniques - how writer John Kaminiates chooses to tell his story: the capture of Thessaloniki in 904 by Arab pirates and the captivation and transport of thousands of inhabitants to Syria. Various aspects of narrative function are examined: the relation between story time and narration time, the form and content of description, the narrator's roles and communication with the reader, the significance of detail, the use of proverbs and metaphors. Finally, an indicative discussion of the influential written forms in Kaminiates's work, is also attempted within the framework of this narrative analysis.

Key words: John Kaminiates, Thessaloniki, Arabs, narrative techniques, ekphrasis, rhetorical progymnasmata, ethopoeia, narrative, epistolography, homeoteleuton, hyperbaton, tautology, adjective nominalization.

Recibido: 28.03.2014 - Aceptado: 30.04.2014

Correspondencia: Spyros P. PANAgopoulos / spyrpan1@gmail.com Licenciado en Filología griega y en Filosofía en la Universidad de Patras (Grecia). Investigador de la filología y historia bizantinas. Candidato al doctorado en los estudios Bizantinos en la Universidad Jónica. 


\section{$\mathbf{I}$}

ntroduction

The case of John Kaminiates ${ }^{1}$ is special in the corpus of medieval Greek literature. His name is associated with a single project, entitled De expugnationae Thessalonicae, describing the capture and the fall of Thessaloniki and the captivity of its residents by Arab pirates in $904^{2}$. In the light of the thematic core of Kaminiates' narrative, the historical event of the capture, scientific research has reasonably assigned this specific work to the canon of medieval Greek historiography. Indicatively, K. Krumbacher ${ }^{3}$ mentions Kaminiates, along with similar reports, in the section on historiography; $\mathrm{H}$. Hunger $^{4}$ in his Literatur sets Kaminiates in the relevant field of middle Byzantine historiography; A. Karpozilos ${ }^{5}$ considers the work as a credible historical source for the tenth century; similar is the assessment of Kaminiates in scientific treatises on the history of the Greek middle ages. Such a view of the text, anyway, is fundamental. Kaminiates refers to historical figures and events attested by other sources. Consequently, the historian who deals with the tenth century derives information from Kaminiates and rightly treats him as a witness for the era.

* This article was presented as a paper at the conference "Literary Crossroads" which took place in Brno, Czech Republic, from 19-22 September 2010. I am greatly indebted to Dr Georgia Markea for having ameliorated the language of the paper.

${ }^{1}$ Gertrud H. Böhlig (1973), Ioannis Caminiatae, De expugnatione Thessalonicae. Corpus Fontium Historiae Byzantinae. Volume IV. Berlin and New York: Walter de Gruyter. Specifically about the adjective Kaminiates, Böhlig (pp. IX-X) etymologies the adjective from the Slavic words kamy, kamene, which mean stone. She also considers possible the Greek origin of the word,

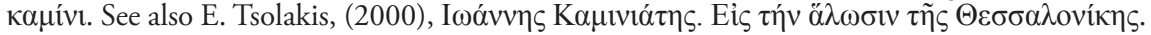
Athens: Kanakis Editions, p. 9, who considers predominant the second etymology, so the

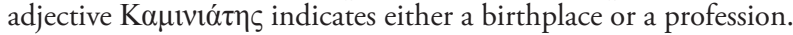

${ }^{2}$ About the exact date of Thessaloniki's fall see D. Frendo- A. Fotiou (2000), John Kaminiates. The capture of Thessaloniki. Byzantina Australiensia 12. Perth: Australian Association for Byzantine Studies, pp. 205-206.

${ }^{3}$ K. Krumbacher, (1897), Geschichte der byzantinischen Literatur. Von Justinian bis zum Ende des oströmischen Reiches (527-1453). München : C.H. Beck'sche Verlagsbuchandlung, pp. 265-266.

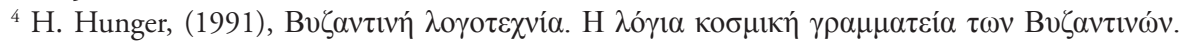
volume 1. Athens: National Bank of Greek Cultural Foundation (M.I.E.T.), pp. 167-170. 
This work, however, aims at highlighting a parallel dimension of the work by John Kaminiates: the exploration of techniques which rule Kaminiates' narrative and help him in the formation of his written testimony. The undoubted historicity of Kaminiates' narrative does not dictate the exclusive treat of it as a historiographic text, as a typical historical source without formal aesthetic claims. On the contrary, this specific work is offered to the scholar not only as a historical source but also as a narrative with literary features. In the case of Kaminiates we do not encounter a conventional listing of events and people. We have a narrative with a clear historical theme, which the author sets out using narrative, literary and rhetorical modes.

The aim of this study is not the declassification of the work as historical, in order to emphasize its literary functional features; its purpose is not to confirm or not the facts inherent in the history of Kaminiates, but the narrative structure of the text. Moreover, the findings of scholars so far do not dispute its factual character. The poverty, but not the lack of historical information attributed to Kaminiates by A. Struck's ${ }^{6}$ and A. Kazhdan's ${ }^{7}$ studies on the authenticity of the work, which raises certain questions, does not remove from the text its referential character ${ }^{8}$.

It has been noted that English medieval literature in particular has been given very little consideration in terms of aesthetics and literary criticism, while the

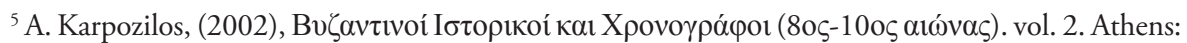
Kanakis Editions, p. 253. Other scholars have also identified Kaminiates' historical usefulness. For example, the text of Kaminiates offers valuable information on marine technology of the 10th century. Cfr. G.K. Livadas, „Some questions of medieval nautical technology in Kameniates” ”Sack of Thessaloniki” (904 AD)“, Graeco-Arabica 6(1995), pp. 145-149. Kaminiates also informs us

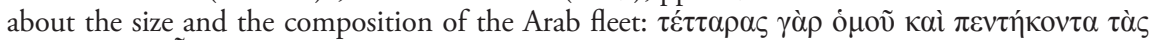

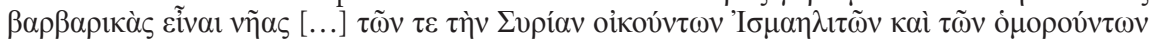

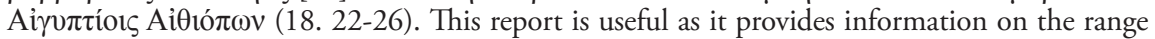
of a naval invasion in the 10th century and certifies the existence of Negro Sudanese sailors in the Arab-Egyptian fleet of the same era. See Livadas 1995 p. 149; R. Khoury Obetallah, (1995), "Leo Tripolites-Ghulām Zurāfa and the sack of Thessaloniki in 904", Byzantinoslavica, 56, pp. 97-100, at p.100; K. Okwess- O’Bweng (1988), "Le portrait du soldat noir chez les Arabes et les Byzantins d'après l'anonyme "Foutouh al-Bahnasâ" et "De Expugnatione Thessalonicae" de Jean

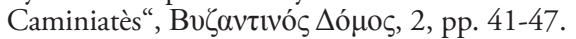

6 A. Struck, (1905), "Die Eroberung Thessalonikes durch die Sarazanen im Jahre 904", Byzantinische Zeitschrift, 14, pp. 535-562.

7 Alexander Kazhdan, (1978), "Some Questions Addressed to the Scholars, who Believe in the Authenticity of Kaminiates' Capture of Thessalonika”, Byzantinische Zeitschrift, 71, pp. 301-314.

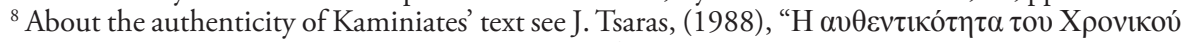

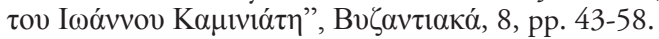


application of modern literary theory to medieval English texts would reveal unknown aspects of these works?. This logic moves the attempt to examine the narrative techniques used by the author Kaminiates. The approach to the text not only externally, focusing on the information it provides about people and events of the period, but also internally, exploring its structure, tries to reveal elements not directly identifiable by the reader. References to the peculiarity of Kaminiates have been made by scholars, and specific elements which reveal literariness have been identified. A. Kazhdan speaks of individuality by Kaminiates and his attempt to create for the reader vivid images ${ }^{10}$. S.V. Poljakova stresses the antiheroic presentation of the narrator-protagonist and considers the emphasis on his personal adventure surprising. ${ }^{11} \mathrm{~V}$. Christides points to the detailed description and ironic self-presentation of the narrator ${ }^{12}$. So, it is characteristic that many of those who have dealt with the work of Kaminiates, focusing on the authenticity of the text, such as A. Kazhdan, and on the historical dimension of the work, such as H. Hunger and A. Karpozilos, or on other issues, such as S.V. Poljakova and $\mathrm{V}$. Christides, distinguished in the text a separate elaboration, particularly in the ways that the author chooses to organize his material, how he organizes his narrative material. This study is a more exhaustive analysis and consolidation of these particular findings ${ }^{13}$.

\section{Narrative Techniques}

The work of John Kaminiates on the capture of Thessaloniki consists of various narrative techniques, which aim at the more faithful rendering of the tragic events of the fall of the city and the enslavement of its inhabitants. It is plausible that, in a study which is going to be published in a journal, the detailed presentation and analysis of narrative techniques should be impossible. For this

${ }^{9}$ See indicatively Rene Wellek, Austin Warren, (1982), Theory of literature. Pelican Books .

${ }^{10}$ Kazhdan 1978 , p. 306.

${ }^{11}$ S.V. Poljakova's study can be found under R.A. Nasledova (1959), Dve vizantijskie chroniki X veka. Moskau, pp. 242-245.

${ }^{12}$ Cfr. V. Christides, (1981), “Once again Kaminiates' Capture of Thessalonica”, Byzantinische Zeitschriftt, 74, pp. 7-10. Christides points out that Kaminiates "takes us far beyond any typical Byzantine historical source of the tenth century" (p. 7). He stresses the realistic description of the conditions in the Aegean (p. 8), as also the earthly character of hero-narrator (p. 9). He compares Kaminiates' protagonists with Digenes Akritas, "two diametrically different types" (p. 9).

${ }^{13}$ The contemporary critical edition of the work was carried out by G. Böhlig in 1973 in the framework of the Corpus Fontium Historiae Byzantinae. The same scholar translated the work into German, R.A. Nasledova into Rusian, D. Frendo \& A. Fotiou into English and J. Tsaras and E. Tsolakis into Modern Greek. Different aspects of the work were dealt with by E. Tsolakis, V. Koufopoulou, E. Papagianni, E. Trapp and J. Koder. 
reason we will focus on the fullest possible presentation of the more important narrative techniques of the text, reserving the right to revert to a future study of ours, which will make full use of the narrative techniques of the author.

Clearly one of the most important techniques of narrative text, is the ekphrasis (rhetorical description) ${ }^{14}$. The ekphrasis covers most of the text and in the sphere of narrative place constitutes a pause. This narrative section does not correspond to a spam of history and is not inserted in the temporal sequence, which starts from the notification of the oncoming pirate attack, nor can we place it in this narrative. As noted in the examination of the temporal relationship of narrative history, with this digression the text transits into a timeless mode. However, apart from the question of narrative organization of time, the question arises: what is the function of ekphrasis in the narrative? Does it serve a specific purpose, and if so, what does it offer to the reader? The author himself provides an initial explanation

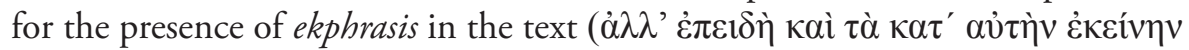

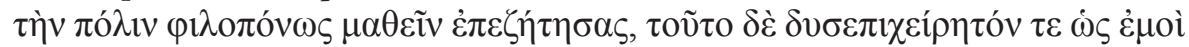

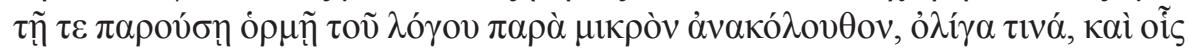

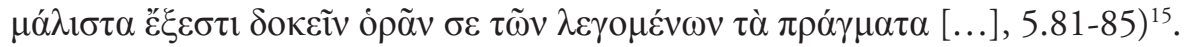
Again, as at the beginning of the narrative (4.34-37), Kaminiates indicates that his attempt as an author is not unsolicited. He writes, because he was asked to by an $\ddot{\alpha} \rho \imath \sigma \tau o \varsigma$ and $\varphi \imath \lambda o ́ \pi о v o \varsigma$ man. So in the case of digression: while he is aware of the literary dimension, he indeed realises what fits and what is inconsistent in recounting a capture, satisfying the keen interest of Gregory in information, he describes the external and internal reality of Thessaloniki. However, in the same proposal he highlights the utility of the, according to him inconsistent, digression: he will describe the city so that not the reader reads he will think is unfolding before his eyes. Consequently, the reason for the existence of the ekphrasis is the need for authenticity in the presentation of events ${ }^{16}$. If the reader

${ }^{14}$ About ekphrasis see the recent study by Ruth Webb, (2009), Ekphrasis, Imagination and Persuasion in ancient rhetorical theory and practice. Farnham: Ashgate Publishing.

${ }^{15}$ Frendo\&Fotiou 2000, p. 5: "But since you asked for detailed information about the physical layout of the city, and that is in my view both a difficult enterprise and one that comes close to conflicting with the present tenor of my discourse, I shall preface my narrative my narrative with a few remarks intended to help you picture the objective reality behind my words [...]”. We must note that D. Frendo \& A. Fotiou follow the pagination of G. Böhlig. We must also note that the first number of the reference (e.g. 4.55-56) indicates the page and not the paragraph, so we judge correctly to follow the same method.

${ }^{16} \mathrm{D}$. Frendo and A. Fotiou give an ideological dimension in the function of ekphrasis, as they consider that it symbolizes the transition from the material to the spiritual: Frendo\&Fotiou 2000, p. xxxiii. 
has a clear picture of the city and its environs, already enlightened, he will find it easier to follow the development of the narrative. Kaminiates 'sets' the essentially scene, which will be played out his history. And he does so successfully. The description of the Thermaic gulf, the port, the walls, the area outside the walls, and the soil morphology within the city is detailed and is demonstrated later in the narrative as useful, since in all these parts the circumstances of the battle and the capture took place.

An additional function of the ekphrasis is associated with the justification of the events of the capture and captivity. Kaminiates describes a city where the abundance of material goods was accompanied by harmonious intellectual and social life. The Thessalonians, however, proved unable to manage their wealth, and, influenced perhaps by foreigners who either as traders or as refugees flocked to the city (13.53-61), everyone was engrossed in how to ensure pleasures for

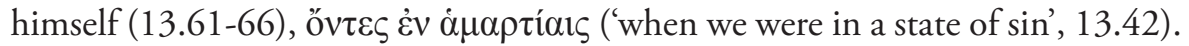
The punishment of the Thessalonians because of their sensualness is an objectlesson for those to come (13.41-50). Furthermore, the positive, excessively deep description of the city accentuates the feeling of sadness that the readers will probably feel, when they subsequently know the details of the disaster. In the ekphrasis is constructed the image of a bright and prosperous city; this image will be dissolved once the battle is lost: the entire city will experience tragic moments and the ideal state of the ekphrasis will give way to the massacre of the

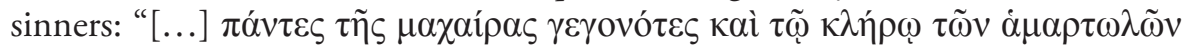

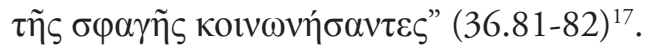

Thus, in the sum, the function of ekphrasis is: referential, since it enlightens the reader offering information about the past, distant and recent, and the present of the city; narrative, providing the framework upon which history will take its course; ideological, as it shows the causes of the capture and contributes to the emotion at charge of the reader, the initial impression of the locus amoenus entirely overturned thereafter.

The ideological and realistic description of Thessaloniki is characterized by completeness. Kaminiates manages to give a satisfactory picture of reality. The main object of the ekphrasis is the city of Thessaloniki; we distinguish, however,

${ }^{17}$ Frendo\&Fotiou 2000, p. 36: "[...] each one of them fell victim to the sword and all were led to the slaughter to share the common lot of sinners". 
bases within this descriptive unity. In the order at which they appear in the ekphrasis the individual units are: the Christian faith of the Thessalonians, the harbour and the bay to the south of the city, the northern, eastern and western environs, the walls and attacks against the city, the self-sufficiency in material goods and trade, and the religious activity of the residents.

The description in the ekphrasis is detailed and analytical and that is manifested by the number and detail of the properties related to each subsection: Thessaloniki is notable for its faith, the fruit of which renders the city rich, $\pi \rho \tilde{\omega} \tau o$

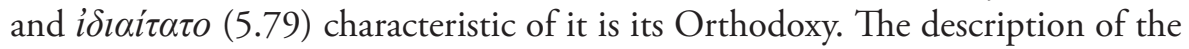
port starts for the security it offers to vessels and extends to the motions of the water, in the bay. The mountain, north of the city, the plains stretching east and west, are presented in a realistic manner and all the products offered to residents are mentioned. The wall to landward is described as É $\rho v \mu v o ́ \tau \alpha \tau o v$ [well-fortified],

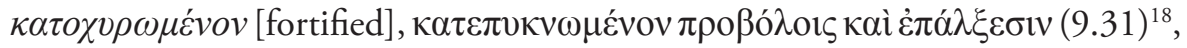
while to seaward as $\chi \theta \alpha \mu \alpha \lambda$ óv, $\pi \rho o ̀ \varsigma \pi o ́ \lambda \varepsilon \mu o v ~ \alpha ̉ \pi \alpha \rho \alpha ́ \sigma \kappa \varepsilon v o v ~(9.33)^{19}$. Regarding the sufficiency of the city, $\gamma \varepsilon \omega \rho \gamma i \alpha \varsigma \alpha \dot{\alpha} \varphi \theta$ ovíar ('the abundance of agriculture',

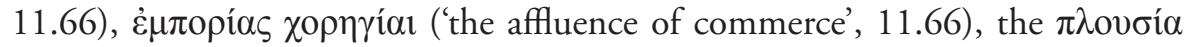
and $\dot{\alpha} \delta \alpha \dot{\alpha} \alpha \omega$ o supply of land and sea (11.67-68) make a reality $(7.36,10.65)$

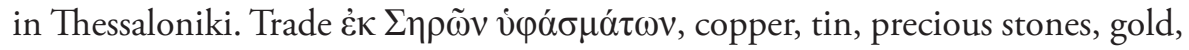

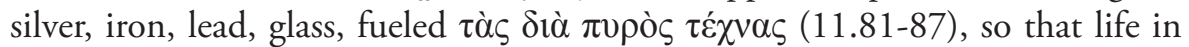
Thessaloniki would get better. The melodies delight the soul, harmonious music and the rhythm of hymns, the zeal of the young for education, compliance with laws and constitution, contribute to the high intellectual and social level of the state. We can say that the description of Thessaloniki by Kaminiates is successful because it is thorough, transmits knowledge to the reader and in relation to the

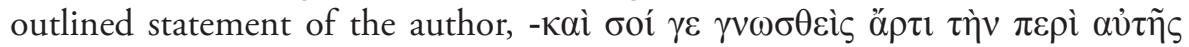

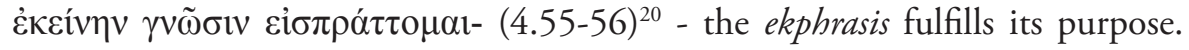
Gregory "is informed" about the homeland of Kaminiates.

The cases where we have a scene with the form of pure dialogue, are few: Kaminiates tries to get in contact with the Ethiopian assaulter, but the answer comes from another Arab who knew Greek with whom he ends the dialogue

${ }^{18}$ Frendo\&Fotiou 2000, p. 9: “[...] everywhere reinforced by a series of wall towers and battlements $[\ldots] "$.

${ }^{19}$ Frendo\&Fotiou 2000 , p. 9: “[...] low, and totally unequipped to deal with a military threat".

${ }^{20}$ Frendo\&Fotiou 2000, p. 4: "Quite recently, since I made your acquaintance, I have been collecting information about her". 
(41.3-42.38). Elsewhere (47.36-48.64), Leo of Tripolis interrogates Kaminiates' father, who also replies to him about his relatives, and finally the Arab assures the father about the safety of himself and his family. In the next dialogue scene Leo of Tripolis asks again the royal eunuch Rodofylis about the luck of the gold he transferred, he is not satisfied with the response of the second one and he orders his execution. On the fourth case (54.72-5), again the leader of the Arabs communicates with $\dot{\alpha} \sigma \eta \kappa \rho \dot{\eta} \tau \iota \varsigma$ Symeon for possible exchange of prisoners, an agreement which is achieved. The use of dialogue in these circumstances is not accidental. In the three cases, something important is at stake: on the first case Kaminiates' and relatives' life, on the second case the Arab leader must give its consent to the agreement that would guarantee life of the first ones, on the fourth case fortune of those prisoners hangs in the balance who could not afford the return trip and their presence was considered harmful by the Arabs. On the third case, the dialogue between the Arab and the Roman officer contributes to the delineation of the Arab's character. The juxtaposition of the very words of Leo makes stronger the negative way in which the narrator presents him elsewhere ${ }^{21}$. The other three dialogues intensify the agony of the moment, they give it vividness and contribute to the "reliability" of Kaminiates' testimony. The narrator does not tell us briefly what happened; on the other hand, these experiences are so strongly imprinted in his memory, so as to be exact even the accurate transfer of those discussed. Reader is left in no doubt about how Kaminiates was saved.

Besides these cases of interactive text, in the category of scene fall cases of pronounced speech by persons of history, a speech that is in quotes, even without a response from the persons to whom the speech is addressed. General Niketas encourages the people of Thessaloniki (25.89-26.13) congratulating them

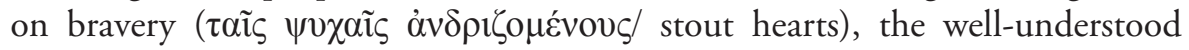
recklessness against the enemies ( $\tau \tilde{\omega} \nu \dot{\alpha} \nu \tau t \pi \alpha \dot{\lambda} \omega \nu \kappa \alpha \tau \varepsilon \gamma \gamma \varepsilon \lambda \tilde{\omega} \nu \tau \alpha \varsigma /$ you scorn the enemy) and urging them to strive, to avoid the great humiliation ( $\tau \tilde{\eta} \varsigma$ $\alpha i \sigma \chi u ́ v \eta \varsigma$ ò $\mu \varepsilon \dot{\varepsilon} \varepsilon \theta$ os/ the depth of your shame). In the scene the author sets, the general's live words fit perfectly: we're just after the first attack by pirates, the

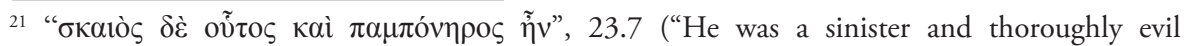

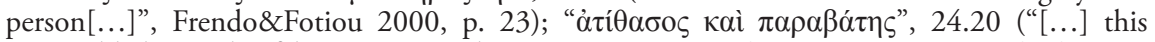

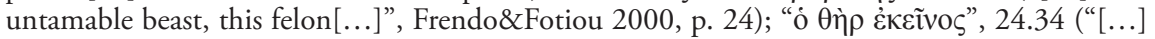

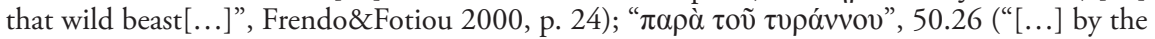
tyrant[...]", Frendo\&Fotiou 2000, p. 50). 
description of movements of both sides is detailed, the momentum of the Arabs is great, but the resistance of the Thessalonians is worthy of the occasion. Once the first wave of attack has been rebutted, ${ }^{22}$ the reader reads the oration of the general and understands clearly the elevated mental state of the beleaguered residents. Elsewhere (33.89-34.11), an elderly father is addressed with a moanful lament to his child, as the line of defense is broken and the Arabs invade the city. Just below (34.15-23), a husband expresses to his wife his confidence for the upcoming end and lists the goods they lose. The intensity of the moment requires also here the existence of living speech. With the impetuous entrance of pirates in Thessaloniki the panic prevails. According to what the narrator says, the people had been wandering as ungovernable boats and had been hanging from each other: "

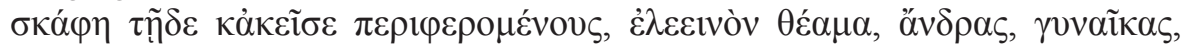

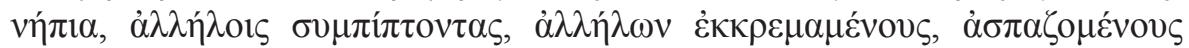

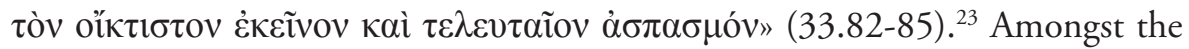
lamented numerous citizens who have poured in the city, the narrative focuses on the father crying together with his child, on the man mourning for his conjugal life, embracing his wife. The aim is to intensify the emotion of the moment, going from the general evil to the particular individual tragedy. Kaminiates offers to his reader realistic moments of pain, not a generic description of disaster. In

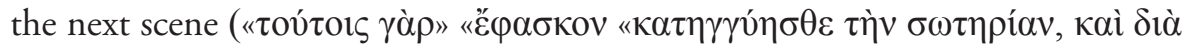

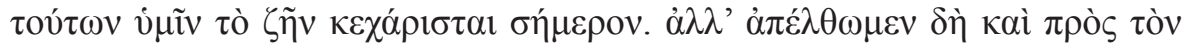

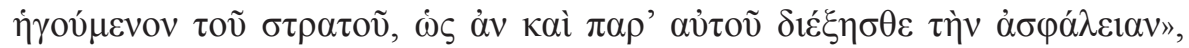
47.17-20), ${ }^{24}$ where the author quotes the identical words of a person, the living speech adds clarity to a crucial point in history. Kaminiates has just delivered the hidden money and the Arabs guarantee their integrity. In two other cases Kaminiates calls upon Leo of Tripolis to speak either to give commands ('Ev

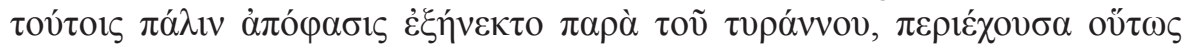

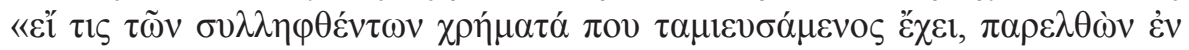

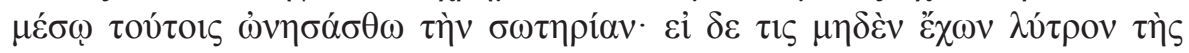

${ }^{22}$ The pirates' retreat was a favourite reconnaissance tactics during the siege of cities (cfr. Christides 2002, p. 93). Kaminiates, however, perceives it as a success of the defenders.

${ }^{23}$ Frendo\&Fotiou 2000, p. 33: "One could see people drifting about aimlessly like ships without a rudder, a pitiful sight; men, women and children throwing themselves on each other, clinging to one another and exchanging the last and most piteous parting embrace".

${ }^{24}$ Frendo\&Fotiou 2000, p. 27 : "'With these things', they said, 'you have guaranteed your safety, and it is thanks to them that we have granted your lives today. But let us go to the commander of the army so that you may receive from him too a full guarantee of safety". 


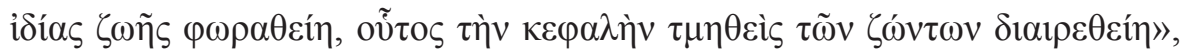

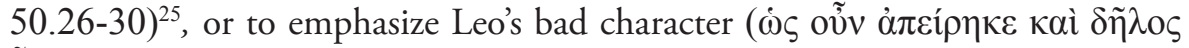

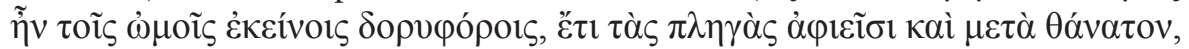

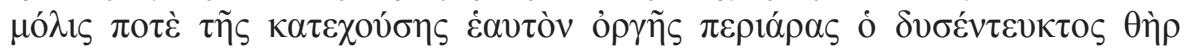

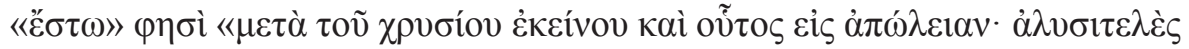

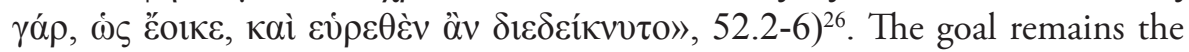

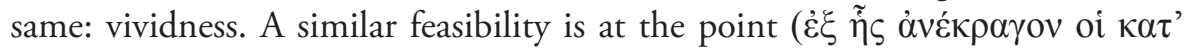

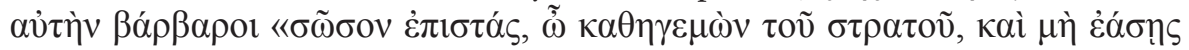

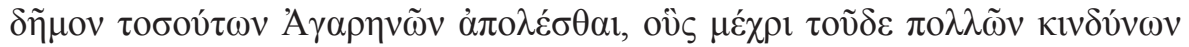

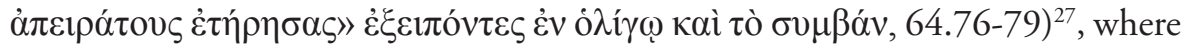
the Arabs beg Leo to save them, as their ship is in danger of sinking ${ }^{28}$. The reader reads the same dramatic words of the pirates, not the matter-of-fact description of the narrator. In all the above cases the author's intention becomes obvious to make the story interesting, appealing. The juxtaposition of living speech gives color to the description and depth to the persons of history. Besides, Kaminiates selects the direct speech in critical moments about the course of events, helping eventually the reader to form a clear picture of what happens.

The narrative comment, as a means of communication between the narrator and the reader, takes also other forms in Kaminiates. In some places the narrator comments the situation arising from the narrative, interrupts the flow of the narrative adding a dramatic tone to his speech. After inserting the direct speech, on the cases of the father and the husband, once both excitement and anxiety about the fate of the inhabitants peaks, having already collapsed any resistance and any moment now the pirates will start the massacre, the narrator

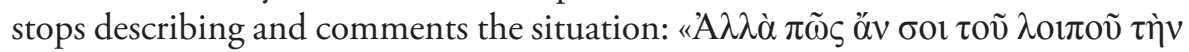

${ }^{25}$ Frendo\&Fotiou 2000, p. 50: "Meanwhile a further decision was issued by the tyrant, to this effect, that 'If any of those who had been apprehended has valuables stored away somewhere, he must come forward and purchase his life with them. But whoever is found to have no means of paying for his life shall have his head chopped off and be separated from the ranks of the living" ".

${ }^{26}$ Frendo\&Fotiou 2000, p. 52: "When he was completely lifeless and was seen to be so by those brutal underlings, even though they kept on lashing him after he was dead, the disgusting beast, barely curbing at last the savage fury that possessed him, said, 'Let him go to hell along with that famous gold! Much good it would do him now, even if it were found!'”.

${ }^{27}$ Frendo\&Fotiou 2000, p. 64: "The barbarians on board called out from the ship: 'Come to our rescue, o commander of the fleet, and do not allow so great a multitude of Hagarenes, whom you have so far preserved unscathed from many dangers, to perish!' ".

${ }^{28}$ Eventually, Leo saves not only the Arabs of the sinking ship, but also the passengers-prisoners, though he initially tried to save only those of the same religion. 


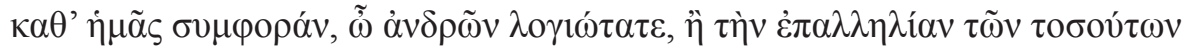

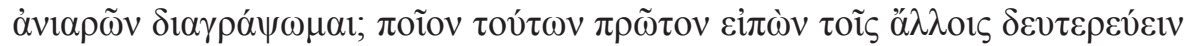

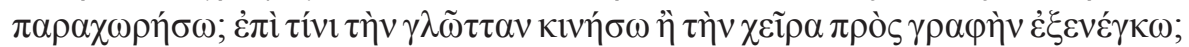

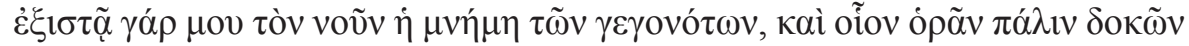

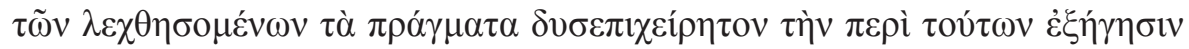

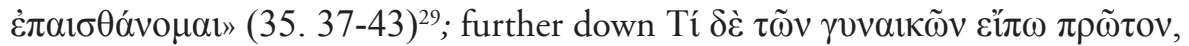

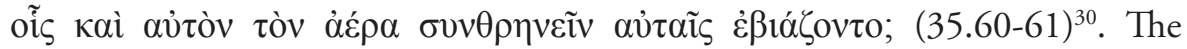
narrator states his unbridled emotion, perhaps with exaggeration. He does not choose, however, an irrelevant moment. He has already raised the tones with the dramatic monologues and he prepares the reader for the greater evil, the slaughter and the disgrace of the inhabitants. Neither, however, he remains unaffected by the psychological charge of the narrative. Not only does he add drama to the description of the conquest, but also he directs vividly even himself at the time of writing. As on the previous case, with the comment a live image is formed, but not for the secondary person that will speak, such as in the scene, but for the main narrator. He concerns about the description, and his emotional state is stated. On the second part of the story, on the description of the route to Syria, the narrative comments exacerbate the very unpleasant feeling caused

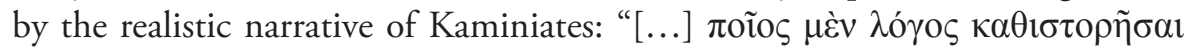

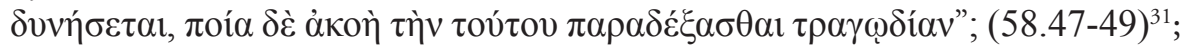

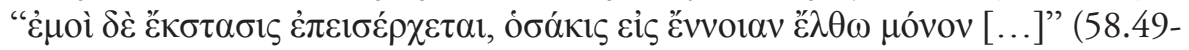
$50)^{32}$. We find the same pattern of incompetence of the written speech to depict the tragedy of the experience. A little further down he expresses that clearly contradicting his statement. An apparent contradiction, as Kaminiates' tendency to underestimate the literary skills obviously is a rhetorical manner, so on the one hand to avoid arrogance and to cause a positive attitude of the reader, on the other hand to help to the dramatization of the scene.

${ }^{29}$ Frendo\&Fotiou 2000, p. 35: "But how from this point on shall I describe to you, o most cultured of men, our misfortune or outline the sequence of so many painful events? Which shall I select for first mention, thereby relegating the rest to second place? To what shall I direct my tongue or apply my hand to the task of writing? The recollection of events drives me to distraction. I seem to see actually happening all over again the things that I am about to relate and am, in consequence, not insensible to the difficulty of embarking on such a narrative".

${ }^{30}$ Frendo\&Fotiou 2000, p. 35: "What shall I say first about the women, who forced the very air to join them in their lamentation?".

${ }^{31}$ Frendo\&Fotiou 2000, p. 58: "And what account will be able to portray [...]?"; "And what ear will be able to entertain the recital of such a tragedy?".

${ }^{32}$ Frendo\&Fotiou 2000, p. 58: "It drives me to distraction just to think of [...]" 
The entire narrative by Kaminiates has the form of a reply to the letters of Gregory. To maintain contact with the recipient-reader, he is addressed to him, especially at the beginning of the text to extol him and ensure, after a fashion,

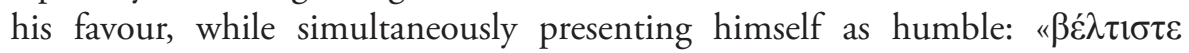

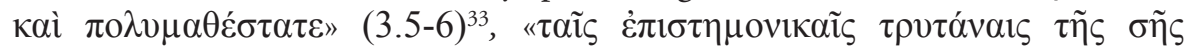

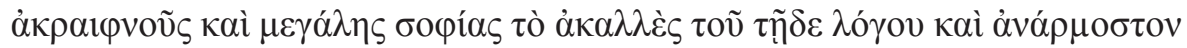

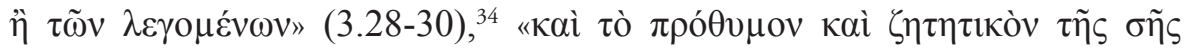

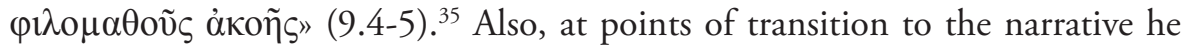

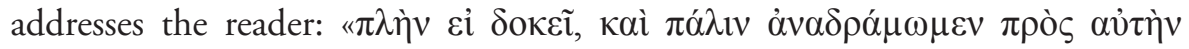

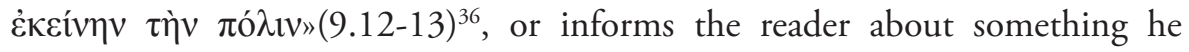

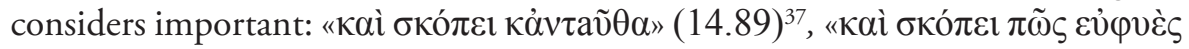

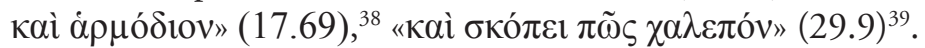

The divine interventionism in Kaminiates is not limited to the general position that the tragic events of the capture and captivity are a correction of sinners. The presence of God is constant but appears in isolated incidents. To the $\pi \alpha \rho \alpha \delta$ o $\xi o \pi 010$ (miraculous) divine providence is owed the salvation of Kaminiates

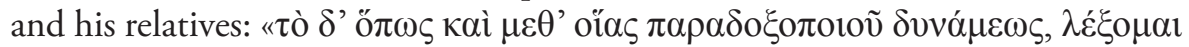
"̌ $\rho \chi \mu \alpha l »(38.80-81) .{ }^{40}$ The divine will acts even for the "infidels": the moment when the Arabs are prepared to kill Kaminiates' family members, second thoughts prevent them from walking onto the bridge separating them from their future victims. This delay enabled Kaminiates to recover from his fear and take the initiative that ultimately will save them. The reluctance of the pirates was put into their mind by o $\tau \tilde{\omega} v \theta \alpha v \mu \alpha \sigma i ́ \omega v \theta \varepsilon$ ó $\varsigma$ (the God of wonders, 41.80). The

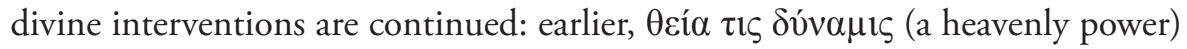
provoked the bravery of the defenders (28.70), while the Arab who knows Greek

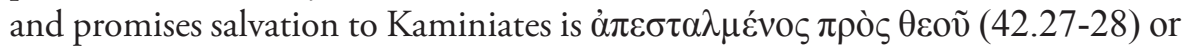

${ }^{33}$ Frendo\&Fotiou 2000, p. 5: "[..] o best and most learned of men[...]".

${ }^{34}$ Frendo\&Fotiou 2000, p. 3: "[...] by the scientific evaluations characteristic of your great and undiluted store of wisdom, and that since the account of what will be said[...]".

${ }^{35}$ Frendo\&Fotiou 2000, p. 9: "[...] the eagerness and insistence of your request for information [...].

${ }^{36}$ Frendo\&Fotiou 2000, p. 9: "But if you think that we should, let us return directly to the subject of the city".

${ }^{37}$ Frendo\&Fotiou 2000, p. 14: "And consider even at this point [...]".

${ }^{38}$ Frendo\&Fotiou 2000, p. 17: "[...] one that was both simple and appropriate".

${ }^{39}$ Frendo\&Fotiou 2000, p. 29: "[...] (and particularly deadly)".

${ }^{40}$ Frendo\&Fotiou 2000, p. 38: "And how it came about and with what manifestation of miraculous power I shall proceed to say". 


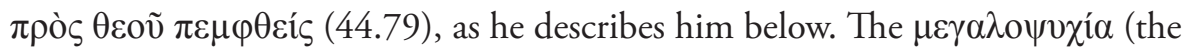
nobility of soul) and will of God (62.85-87) strengthened the mental resources of the prisoners in order to withstand the harsh ordeal of family separation:

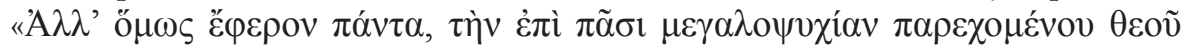

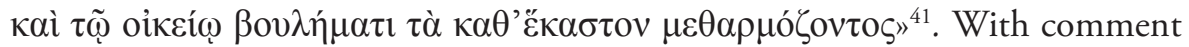
in similar style Kaminiates closes his account: he asks Gregory to pray to God to redeem them either by their release or by patient endurance of their captivity: [...]

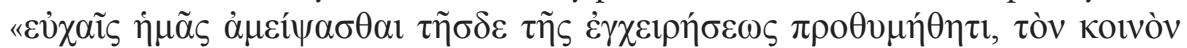

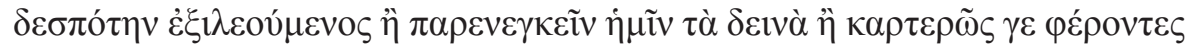

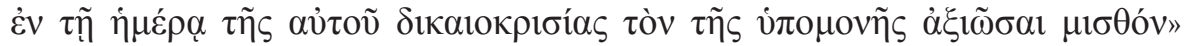
(68.16-19) ${ }^{42}$. The supernatural interventions, however, are not the prerogative

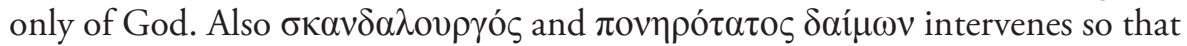
general Leon is wounded seriously, falling from his horse, during his meeting with the other military officer Niketas (19.40). However, it should be noted as follows: Kaminiates is certainly imbued with the Christian worldview on divine intervention in human affairs, but he does not fail to point out in a completely realistic way the physical causes that led to the downfall of the city. Yes indeed, divine punishment led Leo of Tripolis to the gates of Thessaloniki, but the city fell also because of the inadequate construction of the sea wall (17.69-76), the military inexperience of the Thessalonians (16.49), and the faith-heartedness which the inhabitants finally showed during the siege.

The author uses rhetorical devices and expressive means to enrich his narrative. There often appears in the course of the text a series of rhetorical questions that reflect the desperation of the narrator in the face of his tragic experiences, his inability to accomplish his writing calmly, and present in a dramatic way the

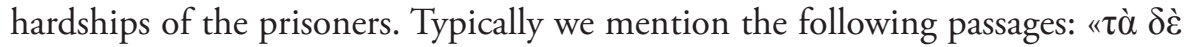

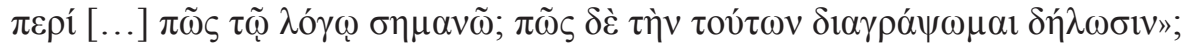

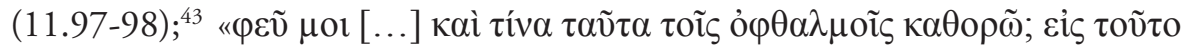

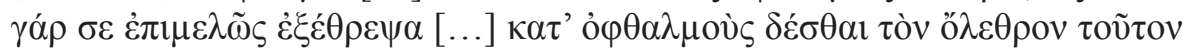

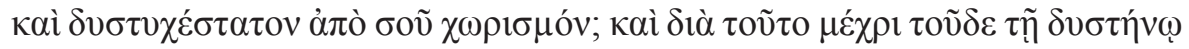

${ }^{41}$ Frendo\&Fotiou 2000, p. 62: "Yet they bore everything, for God provided the nobility of soul to cope with each eventuality and regulated every detail according to His will"

${ }^{42}$ Frendo\&Fotiou 2000, p. 68: "[...] to repay (our endeavor) with your prayers and prevail our Common Master either to avert disaster from us or, provided that we bear it all with fortitude, to reward our patience on the day of His righteous judgement".

${ }^{43}$ Frendo\&Fotiou 2000, p. 11: "But how can I convey in language [...]? But how could I set down in writing a meaningful account of these matters?". 


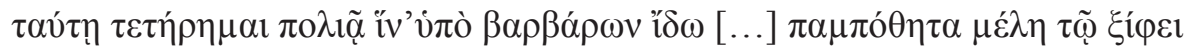

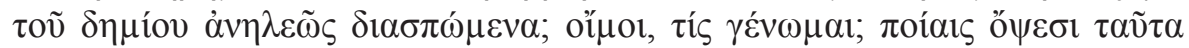

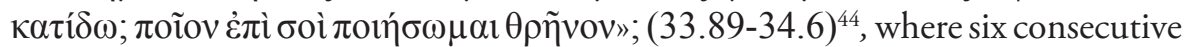

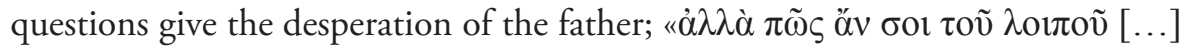

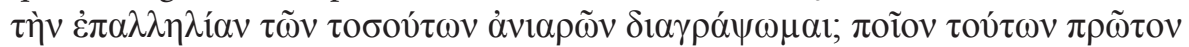

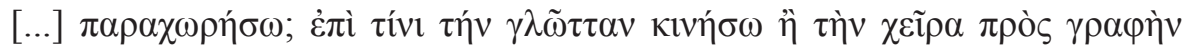

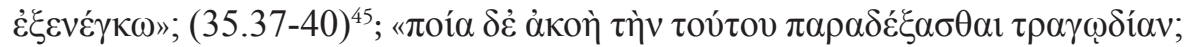

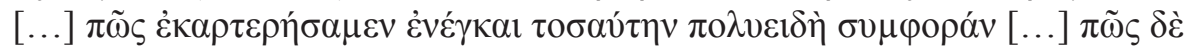

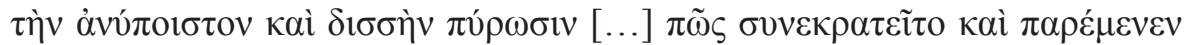

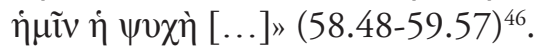

Serving his pursuit of living storytelling, Kaminiates vividly colours his diction using maxims, similes, and metaphors. Without Kaminates declaring their instigator,

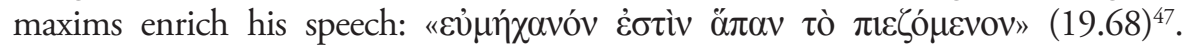
Crowds of people flocked to Thessaloniki, so it was easier to measure the sand on

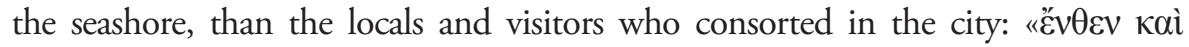

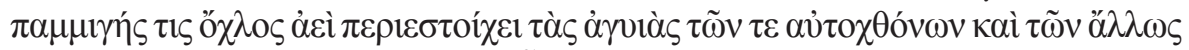

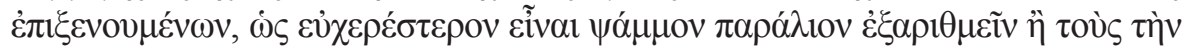

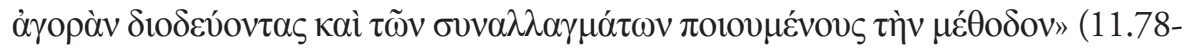
$81)^{48}$. The same aphorism repeated for the multitude of disasters experienced by

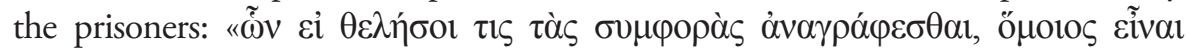

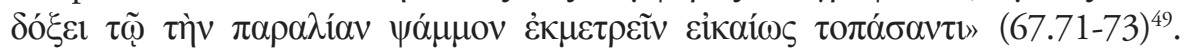

${ }^{44}$ Frendo\&Fotiou 2000, p. 33: "Woe is me, [...] and what things are these, which my eyes behold? Was it for this that I reared you diligently [...], is it just at such a moment that I must gaze upon this disaster and this most unhappy separation? And have I been kept alive till now with this unhappy head of gray hair simply in order that I may behold your body (disfigured) by barbarians, and the beloved limbs I long to embrace pitilessly hacked asunder by the executioner's sword? Alas, what is to become of me? With what eyes shall I look upon these happenings? What funeral dirge shall I utter on your account? [...]".

${ }^{45}$ Frendo\&Fotiou 2000, p. 35: "But how from this point on shall I describe to you [...] the sequence of so many painful events? Which shall I select for first mention, thereby relegating the rest to second place? To what shall I direct my tongue or apply my hand to the task of writing?"

${ }^{46}$ Frendo\&Fotiou 2000, p. 58: "And what ear will be able to entertain the recital of such a tragedy? [...] how we had the fortitude to bear so abundant and so varied an array of misfortunes [...]. How did we bear the unendurable double scorching [...] and how [...] did our souls remain steadfast $[\ldots]$.

${ }^{47}$ Frendo\&Fotiou 2000, p. 19: " 'necessity is the mother of invention' ".

${ }^{48}$ Frendo\&Fotiou 2000, p. 11: "In consequence, a motley crowd of foreigners and townspeople thronged the streets, so that it was easier to count the sands on the seashore than to count the numbers of those passing through the marketplace and carrying out their various transactions".

${ }^{49}$ Frendo\&Fotiou 2000, p. 67: "And if anyone wished to record their misfortunes he would be like a man trying to arrive by guesswork at the precise number of grains of sand on the seashore". 
The presence of similes and metaphorical phrases is widespread in

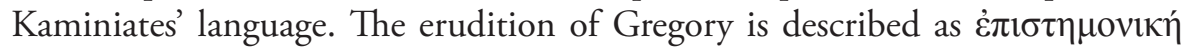
$\tau \rho v \tau \alpha \dot{v \eta} \eta(3.29)^{50}$. He uses the simile familiar in the theological texts of faith as the seed and grain (4.60-5.77). The hymns, which are heard from groups

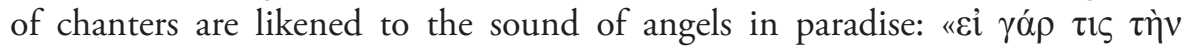

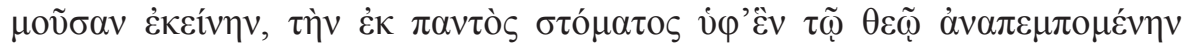

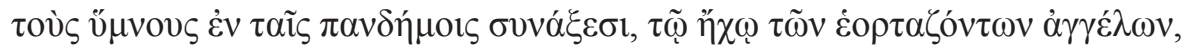

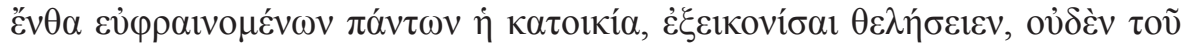
$\delta \varepsilon \dot{0} \tau \tau ం \varsigma \dot{\alpha} \mu \alpha \rho \tau \eta ́ \sigma \varepsilon \tau \alpha 1 »(12.11-14) .^{51}$ The pirates are often likened to wild beasts (18. 26-27, 23.7, 24.34, 25.59, 28.78, 36.10, 40.5, 45. 47-48) and they have

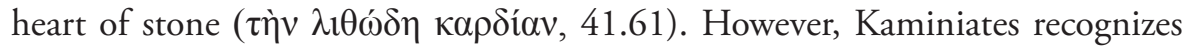
the selflessness shown by pirates and compares them with bronze statues which

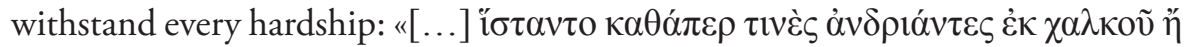

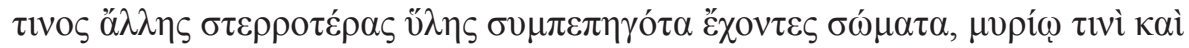

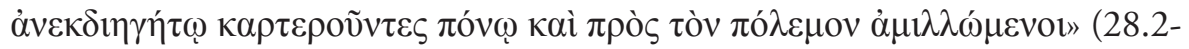
$5)^{52}$. When he recounts the gruelling passage to Syria, along with the intense realism, are shown again similes to intensity the impressions. The dirty water,

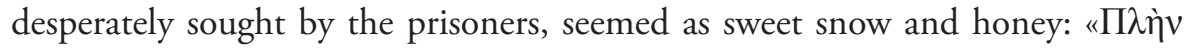

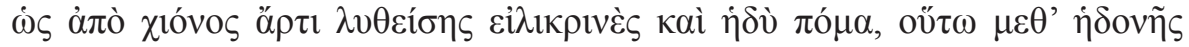

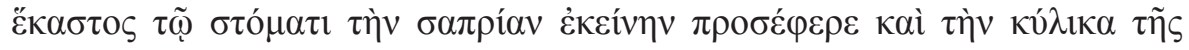

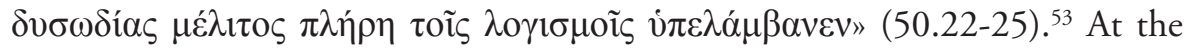
moment of reunification of families in Crete, the children ( [oi $\pi \alpha \tilde{i} \delta \varepsilon \varsigma] \kappa \alpha \theta \dot{\alpha} \pi \varepsilon \rho$

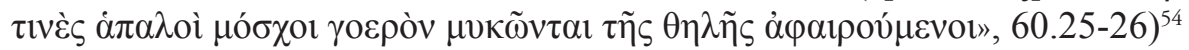

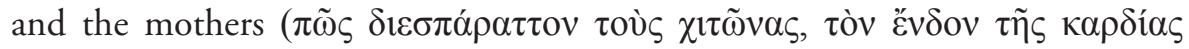

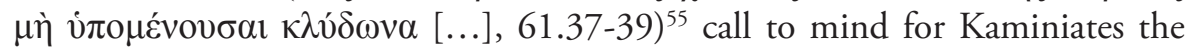

${ }^{50}$ Frendo and Fotiou translate this phrase as "scientific evaluations".

${ }^{51}$ Frendo\&Fotiou 2000, p. 12: "If one were to liken that music which during the celebration of divine wells up of one accord from every lip in hymns of praise to God, if one were to liken such music to the sound of the angels 'keeping holyday' in the place where stands 'the above of all those who rejoice', he would be drawing a perfectly legitimate comparison".

${ }^{52}$ Frendo\&Fotiou 2000, p. 28: "[...] they stood like statues with bodies of bronze or some other hard material and displayed limitless qualities of endurance and a fighting spirit that defied description".

${ }^{53}$ Frendo\&Fotiou 2000, p. 50: "Yet each one of us joyfully put that disgusting filth to his lips as though it were a sweet, pure draught of newly-melted snow and in his imagination took the cup of stinking liquid for a cup filled with honey"

${ }^{54}$ Frendo\&Fotiou 2000, p. 60: "[The children] like tender young calves that bellow piteously when they are being weaned".

${ }^{55}$ Frendo\&Fotiou 2000, p. 61: "How, unable to restrain the tide of their emotions, they tore of their emotions?". 


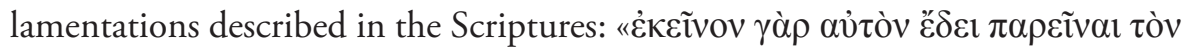

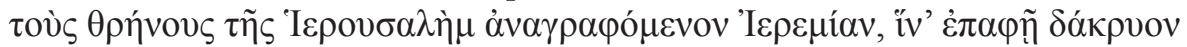

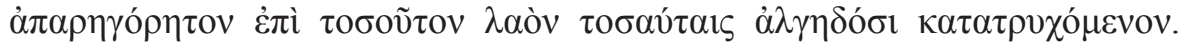

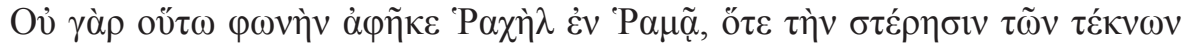

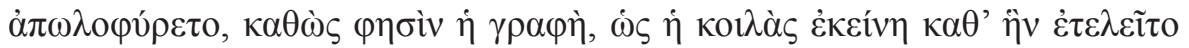

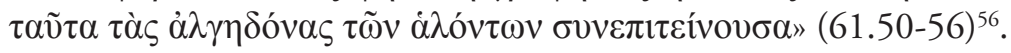

There is no lack of personifications in the author's expressive measures. The

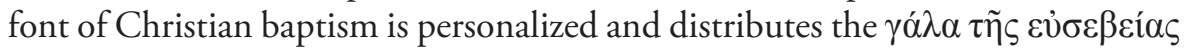

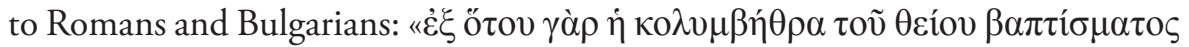

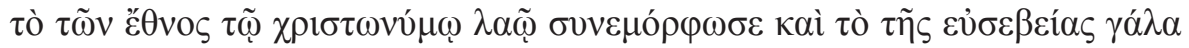

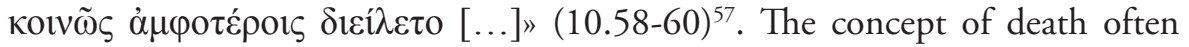
"comes to life" and takes on human characteristics. The death that threatened

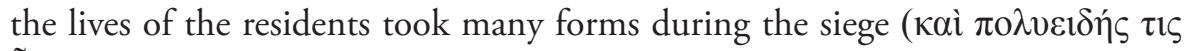

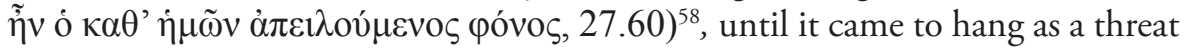

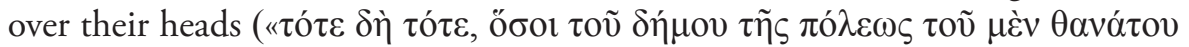

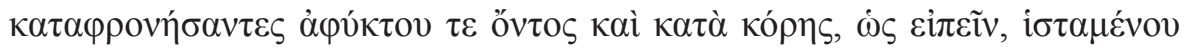

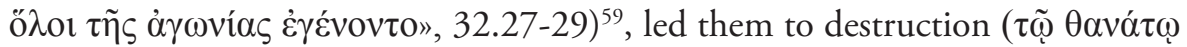

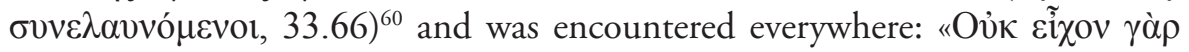

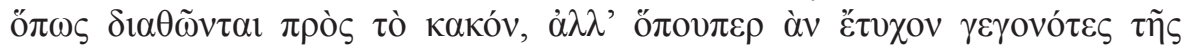

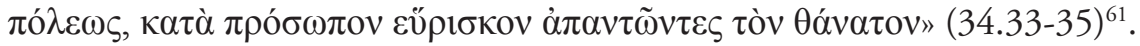

Kaminiates not only cared for the completeness and substantiation of his description as far as the events of history were concerned, but also for the

${ }^{56}$ Frendo\&Fotiou 2000, p. 61: "No louder was the cry that Rachel uttered in Ramah when, as Scripture tells us, she mourned the loss of her children, than was the cry that was sent up by the valley which was the scene of these vicissitudes, when it caused the prisoners' woes to echo over its entire length". Compare this sentence with Jer 31:15 "This is what the LORD says: "A voice is heard in Ramah, mourning and great weeping, Rachel weeping for her children and refusing to be comforted, because they are no more", and Mt 2:18 "“In Ramah was there a voice heard, lamentation and weeping and great mourning, Rachel weeping for her children and would not be comforted, because they are no more."

${ }^{57}$ Frendo\&Fotiou 2000, p. 10: "And in fact, ever since the sacrament of baptism had brought the Scythian people into the Christian fold and had made them share in the milk of true piety [...]".

${ }^{58}$ Frendo\&Fotiou 2000, p. 27: "Death threatened us in many ways in many shapes [...]".

${ }^{59}$ Frendo\&Fotiou 2000, p. 32: "Whereupon, all that part of the population of the city that had come to think nothing of death, since it was both inevitable and staring them, so to speak, in the face $[\ldots] "$.

${ }^{60}$ Frendo\&Fotiou 2000, p. 33: “[...] herded together by death [...]”.

${ }^{61}$ Frendo\&Fotiou 2000, p. 34: "They did not know how to react to the disaster, but in whatever part of the city they happened to be, they found themselves confronted with the prospect of death [...]". 
enrichment of his expressive measures. The images he attempts to represent with vivid and detailed description are not intended solely to clarify the events; he is as interested in informing the readers, as in trying to stir their emotions. He attempts to achieve this by enhancing his language with rhetorical and expressive measures. His realism coexists with an intense emotional charge which he himself experiences and tries to convey to Gregory.

The way in which Kaminiates tells his story will be eluminated more clearly, if as far as possible, any literary influences in his work are sought out. We saw in the introduction that scholars focus on the referential element in the text and use it primarily as a historical source. At the same time, many point out something special in the case of Kaminiates. Whether it is the individuality in the description (A. Kazhdan) the anti-heroic presentation of the narrator (S.V. Poljakova) or the amazing vividness (H. Hunger), the reading of the text raises questions about its component elements. The validity of the historical information given to us, since indisputably the writing of the work is basically of the tenth century, is proven. There is, however, the question: is Kaminiates aware that the written statement of his experience belongs to a literary type and, consequently, follows rules for a specific type of writing, or do we have a text of mixed literary identity, which is a synthesis of various literary influences?

The work should not be compared with historical accounts, narratives of events, but exactly with the epistolographic tradition, but according to Paolo Odorico we can think that the author follows the rules of a literary genre which remains to be studied, that of "roman of captivity" (roman de captivité). ${ }^{62}$ The first fact is that Kaminiates writes a response to the letter from Gregory of Cappadocia ${ }^{63}$. With a cursory glance, however, we see the initial incompatibility of the work with one of the basic rules of correspondence, as they had been

${ }^{62}$ Cf. the excellent article by Paolo Odorico, "Les trois visages de la même violence: les trois prises de Thessalonique", in: Paolo Odorico, Panagiotis A. Agapitos, Martin Hinterberger (2006), L'écriture de la mémoire. La littéralité de l'historiographie. Actes du IIIe colloque international philologique "EPMHNEIA», Centre d'études byzantines, néo-heléniques et sudest européennes, Paris: Écoles des Hautes Études en Sciences Sociales, pp. 48-160. Odorico states also that Kaminiates' account is a "récit autobiographique", ibid. p. 1581. See also the study by A. Markopoulos about historical biography, A. Markopoulos, (2009), "From narrative historiography to historical biography. New trends in Byzantine historical writing in the 10th11 th centuries", Byzantinische Zeitschrift, 102/2, pp. 697-715.

${ }^{63}$ Gregory's letter to Kaminiates is placed from mid-October to the end of October 904 and Kaminiates' "response" by the end of September 905, when began the exchange of prisoners between Arabs and Romans. See Frendo\&Fotiou 2000, p. xxix. 
formulated in late antiquity: conciseness. This does not mean that Kaminiates ignores this particular rule in any way. He often justifies his wordiness (8.1-2, 15.31) and he does not desire to break the law of symmetry (4.47-50), which he eventually fails to do (or did not want to do). The other basic requirement, however, of a successful letter, namely clarity, Kaminiates generally tries to respect. His narrative briefs the reader topographically with the ekphrasis and illuminates every detail of events, without temporal gaps and inaccuracies in the content. The encomium of Gregory by the author (3.3-13) and the parallel projection of his own ignorance (3.19) are characteristic features of epistolary language, in order to build the right psychological mood in the readers, so that they are sympathetic towards the writings. Moreover, the introduction to the text fulfills the same role as the preamble to a letter. It is a greeting to the recipient, includes an encomium to him and provides an initial indication of the topic of the writing. In some letters the position of the preamble is occupied an ekphrasis of place; the placement of Thessaloniki's ekphrasis by Kaminiates, in addition to the added functions which it performs in the course of the text, may be associated with this particular literary tactic.

Mentioned earlier were rhetorical means of expression, similes, metaphors, personifications, that Kaminiates uses in his language. Besides those already mentioned it is ascertained that Kaminiates uses additional rhetoric means:

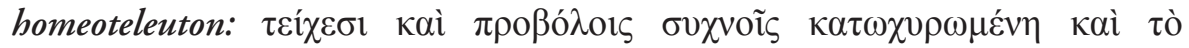

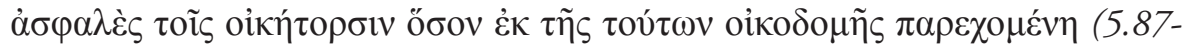

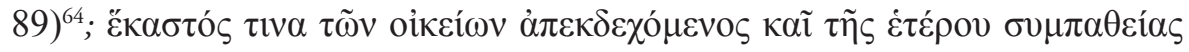

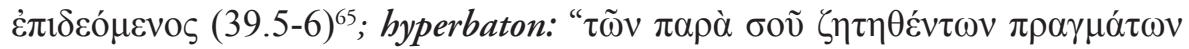

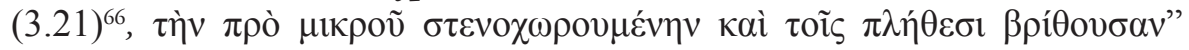

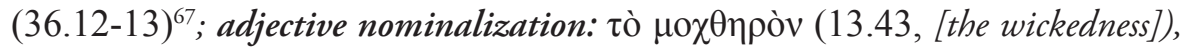

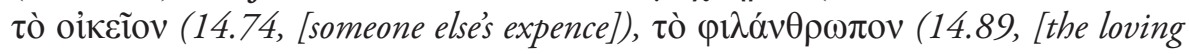

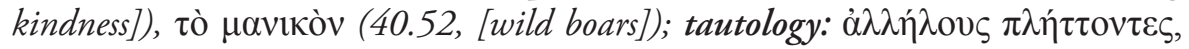

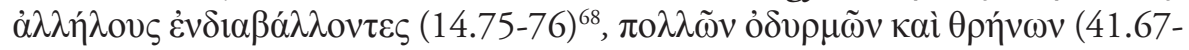

${ }^{64}$ Frendo\&Fotiou 2000, p. 5: "The city is [...] with extensive walls and fortifications affording the inhabitants the full security associated with such defensive structures".

${ }^{65}$ Frendo\&Fotiou 2000 , p. 39: "[...] each one attends anxiously the fate of a relative, all are in need of a shoulder to cry on".

${ }^{66}$ Frendo\&Fotiou 2000, p. 3: "[...] the events you had asked me to relate [...]".

${ }^{67}$ Frendo\&Fotiou 2000 , p. 36: "[...] what had been a crowded and populous city[...]".

${ }^{68}$ Frendo\&Fotiou 2000, p. 14: “[...] engaging all the while in mutual deception, violence, calumny $[\ldots] "$. 


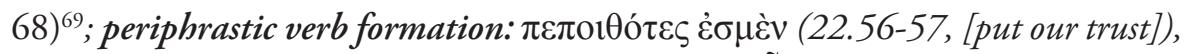

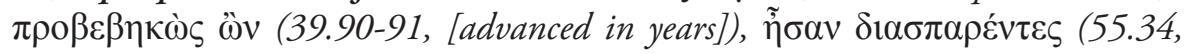
[they had been dispersed]). The effect of the rhetorical art on the text is varied. It is not only about expressive modes, but has affected the whole structure of the narrative. An obvious rhetorical element is the ekphrasis of Thessaloniki. Although A. Kazhdan ${ }^{70}$, he initially considers this paradoxical, since in Byzantine literature descriptions of cities appear in the 13 th century and $a f t e r,{ }^{71}$ he locates the ultimate model for Kaminiates in encomia of cities by the rhetor Menander (3rd century A.D. $)^{72}$. Indeed, the description of Thessaloniki by Kaminiates combines the rhetorical genre of ekphrasis with the encomium of a city. Besides, ekphrasis and encomium "are closely linked throughout the whole of the Byzantine era", so it is a question of encomiastic ekphrasis. We do not have merely the topographic presentation of the environs and the inner city. Thessaloniki is celebrated as a place of the cultivation of Christian piety and faith, of development of the arts, and as a self-sufficient centre of commercial and economic activities. Rhetorical theory defines ekphrasis as an accurate description, which sets before us the object

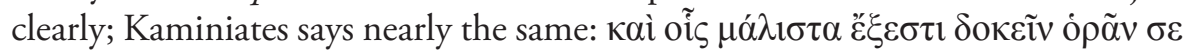

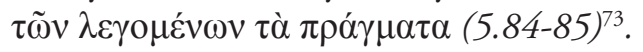

The influence of another rhetorical progymnasma, that of ethopoeia ${ }^{74}$, we find in the direct speeches that Kaminiates inserts in the text, in the words of father to his son (33.89-34.11) and of the husband to his wife (34.15-23). It was mentioned above that it is difficult for Kaminiates, within the general confusion, to understand exactly what was said in the personal conversations of the inhabitants. It is certainly possible that such scenes were enacted in the streets of Thessaloniki, when the lives of all the inhabitants were directly threatened. What is of interest here is Kaminiates' attempt to fashion these words in such a way, as to match the moment of their expression. This is precisely what rhetoric was aiming at with ethopoeid: what such-and-such a man said, whether

${ }^{69}$ Frendo\&Fotiou 2000 , p. 41: "[...] for abundant wailing and lamentation”.

${ }^{70}$ Kazhdan 1978 , p. 304.

${ }^{71}$ Kazhdan is referred to the ekphraseis of Nicaea by Theodore B' Laskaris and Theodore Metochites, as also to the panegyrics of Trebizond by Bessarion and John Eugenicus.

${ }^{72}$ Hunger 1991, pp. 196-213; D.A. Russell, N.G. Wilson (1981), Menander Rhetor. Oxford: Clarendon Press,

${ }^{73}$ Frendo\&Fotiou 2000 , p. 5: "[..] intended to help you picture the objective reality behind my word $[\ldots]$ ".

${ }^{74}$ About the rhetorical progymnasma of ethopoeia see George Kennedy (1994), A new History of Classical Rhetoric. Princeton: Princeton University Press. 
it be about a particular person or about a man who is identified only by the situation in which he is found, in a particular circumstance. The tragic moments of the Arabs' invasion establish inordinate dramatism and emotion. A similar elaboration underlay the speech of Kaminiates' father to his children shortly before their arrest. In this particular case Kaminiates would have certainly heard very well what his father said (39.91-40.45). Again, however, the reader reads an extended (perhaps longer than what the moment would permit) speech with an increased emotional charge. The impression is created that Kaminiates enhances his father's words and gives them a more coherent image.

\section{Conclusion}

The study of the narrative techniques in Kaminiates' text and the summary review of particular literary influences on it, lead to the following conclusion: it is difficult drawing elements exclusively from the text for lack of other sources, to argue that Kaminiates was aware of the genre to which his writing belonged, and of the rules he should have followed. It appears that he accepted influences, normal for a Byzantine writer, from types of language cultivated ad nauseam in medieval times: historiography, chronography, rhetoric, epistolography. The way he was influenced by them, if indeed he had access to theoretical texts of late antiquity or simply had read medieval works, through which he received influences, is currently impossible to verify. The narrative analysis, however, revealed a writer who seeks "credibility" in his work: he does not leave logical gaps in the course of the plot, gives pace to the narrrative, knows when and where, using rhetorical modes, to enhance the dramatism and intensity, describes fully both the spatial the temporal context in which the events unfolded, but also follows the action closely achieving clarity in his language. He focuses as much on the general plot as on his personal adventure; so he provides a complete picture of Thessaloniki's capture in 904 and of the captivity of its thousands of inhabitants. Kaminiates catches the attention of the reader and scholar, because he offers a more realistic description of ordinary medieval people compared with the imperial-aristocratic families and the high-ranking military of historiography-chronography, and the idealized figures of christian saints and martyrs of religious literature. This image is emotionally charged and acquire, additional interest, as it is constructed during the course of a human disaster.- 


\section{Bibliography}

BöHlig, Gertrud H., (1973), Ioannis Caminiatae, De expugnatione Thessalonicae. Corpus Fontium Historiae Byzantinae. Volume IV. Walter de Gruyter, Berlin and New York.

Christides, V., (1981), “Once again Kaminiates' Capture of Thessalonica”, Byzantinische Zeitschriftt 74, 7-10.

Frendo, D., Fotiou, A., (2000), John Kaminiates. The capture of Thessaloniki. Byzantina Australiensia 12. Australian Association for Byzantine Studies, Perth.

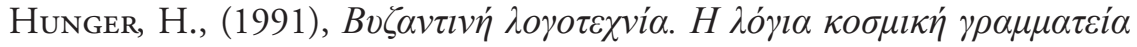

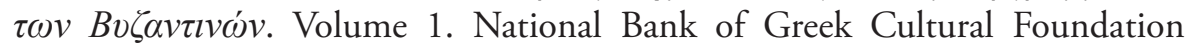
(M.I.E.T.), Athens.

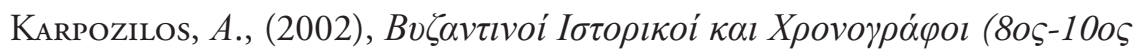
alóvas). Vol. 2. Kanakis Editions, Athens.

Kazhdan, Alexander, (1978), "Some Questions Addressed to the Scholars, who Believe in the Authenticity of Kaminiates' Capture of Thessalonika”, Byzantinische Zeitschrift 71, 301-314.

Kennedy, George, (1994), A new History of Classical Rhetoric. Princeton University Press, Princeton, New Jersey.

Khoury Obetallah, K., (1995), "Leo Tripolites-Ghulām Zurāfa and the sack of Thessaloniki in 904", Byzantinoslavica 56, 97-100.

Krumbacher, K., (1897), Geschichte der byzantinischen Literatur. Von Justinian bis zum Ende des oströmischen Reiches (527-1453). C.H. Beck'sche Verlagsbuchandlung, München.

LivadAs, G.K., (1995), "Some questions of medieval nautical technology in Kameniates' "Sack of Thessaloniki”" (904 AD)", Graeco-Arabica 6,145-149.

Markopoulos, A., (2009), "From narrative historiography to historical biography. New trends in Byzantine historical writing in the $10^{\text {th }}-11^{\text {th }}$ centuries", Byzantinische Zeitschrift 102/2, 697-715.

Nasledova, R.A., (1959), Dve vizantijskie chroniki X veka. Moskau.

Odorico, Paolo, "Les trois visages de la même violence: les trois prises de Thessalonique", in: Odorico, Paolo, Agapitos, Panagiotis A., Hinterberger, Martin, (2006), L'écriture de la mémoire. La littéralité de l'historiographie. Actes 
du IIIe colloque international philologique «EPMHNEIA», Centre d'études nyzantines, néo-heléniques et sud-est européennes, Écoles des Hautes Études en Sciences Sociales, Paris, 148-160.

Okwess-O’Bweng, K., (1988), "Le portrait du soldat noir chez les Arabes et les Byzantins d'après l'anonyme "Foutouh al-Bahnasâ" et "De Expugnatione

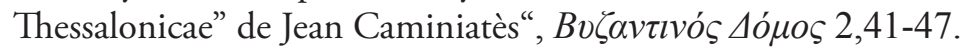

Russell, D. A., Wilson, N.G., (1981), Menander Rhetor. Clarendon Press, Oxford.

Struck, A., (1905), "Die Eroberung Thessalonikes durch die Sarazanen im Jahre 904", BYZANTINISCHE ZEITSCHRIFT I 4, 535-562.

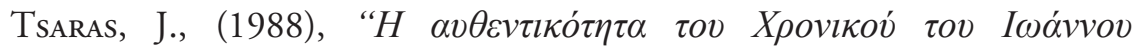

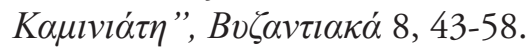

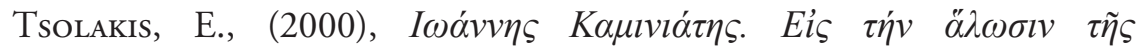
$\Theta \varepsilon \sigma \sigma \alpha \lambda$ ovíkns. Kanakis Editions, Athens.

Webв, Ruth, (2009), Ekphrasis, Imagination and Persuasion in ancient rhetorical theory and practice. Farnham, Ashgate Publishing.

Wellek, Rene, Warren, Austin, (1982), Theory of literature. Pelican Books . 